\title{
感染症シリーズ 8
}

\section{ウイルス性下痢症（ロタウイルス，ノロウイルスなど） \\ 沖津 祥子牛島 廣治 \\ 日本大学医学部病態病理学系微生物学分野}

(J. Nihon Univ. Med. Ass., 2018; 77 (1): 3-6)

\section{1. はじめに}

ウイルス性下痢症は世界中で乳幼児の罹患率，死亡率 の高い疾患の一つとして知られている。年間約 578,000 人の乳幼児がこの疾患のため死亡すると推定されてい る1．日本を初めとする開発国では罹患，死亡とも減少 してきているが，開発途上国では今でも主要な子どもの 死亡原因の一つとなっている。開発国で問題とされるの は罹患率の高さで，その経済的負担は大きい。病因とな るウイルスの種類は多く，ロタウイルス，ノロウイルス を初めとして，多様なウイルスがその原因となる。本稿 ではロタウイルス，ノロウイルスを中心として，ウイル スの特徵, 疫学, 診断方法, 予防法について述べる.

\section{2. ウイルス学的特徵}

\section{（1）ロタウイルス}

ロタウイルスは 1973 年に Bishop によって急性下痢症 で入院した幼児の十二指腸生検標本から発見された。 70 〜 75 nm の粒子状構造をしており，エンベロープを持た ない，遺伝子は 11 本の分節からなる二本鎖 RNA であ る。レオウイルス科に分類され，少なくとも 9 種（A か ら J）があり，そのうちの A， B， C， H がヒトに感染す る。乳幼児の感染症として世界中で重要な病因となる口 タウイルスは $\mathrm{A}$ 種であるため, 本稿では $\mathrm{A}$ 種をロタウ イルスと称する。ロタウイルスのゲノムは約 $18.5 \mathrm{~kb} の$ サイズからなり，11 本の遺伝子分節は 6 つのイルス 蛋白 (VP1，VP2，VP3，VP4，VP6，VP7) と 5 または 6 つの非構造蛋白 (NSP1，NSP2，NSP3，NSP4，NSP5/6) をコードしている。 ウイルス粒子の最外款にあるVP7 とVP4 蛋白を利用した分類法が一般に利用され，これ は $\mathrm{G}$ 血清型，P 血清型と呼ばれていたが，近年では遺伝 子の配列によって分類され，遺伝子型と呼ばれている. ヒトでは少なくとも 14 の $\mathrm{G}$ 遺伝子型， 17 の $\mathrm{P}$ 遺伝子型 による 80 以上の異なる組み合わせが検出されているが, これまでの世界各地での疫学調査の結果から G1P[8], $\mathrm{G} 2 \mathrm{P}[4], \mathrm{G} 3 \mathrm{P}[8], \mathrm{G} 4 \mathrm{P}[8]$ および G9P[8] が最も一般的な 組み合わせとされている2)。一方，11 本すべての遺伝子 型を用いた分類法が近年提唱されている゙3).

\section{（2）ノロウイルス}

1968 年にアメリカのオハイオ州ノーウォーク市の小 学校で発生した集団食中毒の便検体から 1972 年に電子 顕微鏡で検出されたことが最初の発見であった。 カリシ ウイルス科に属し，エンベロープのない一本鎖プラス直 鎖 RNA を遺伝子として持つ直径 30〜38 nm とロタウイ ルスよりも小さな粒子である。ゲノムは $7.3 \sim 8.3 \mathrm{~kb} の$

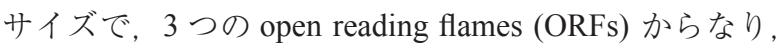
非構造蛋白をコードする ORF1, 構造蛋白のうちカプシ ド蛋白をコードする ORF2 と minor 蛋白をコードする ORF3 からなる。国際ウイルス命名委員会 (ICTV) では ノロウイルス属には唯一の種である Norwalk virus が存 在する。ORF2 の配列の相同性から genogroup $(\mathrm{G})$ が I か ら VII に分けられており, このうちI，II，IVがヒトに 感染する. GI はさらに 16 以上, GII は 23 以上の遺伝子 型に分類される。 ヒトでの乳幼児の感染や集団食中毒の 原因となるノロウイルスはGII が主である。さらに ORF1 と ORF2 の junctional regionにおいて組み換えが起 きることから ORF1 と ORF2 の配列を元にした命名法が 提唱されている4).

\section{（3）その他のウイルス}

下痢に関係するロタウイルス，ノロウイルス以外のウ イルスとしてアデノウイルス，ヒトアストロウイルス， サポウイルスが知られている。 アデノウイルスは呼吸器, 目などの感染症としても知られているウイルスであるが, 腸管にも感染する。主として腸管に感染するアデノウイ ルスは $\mathrm{F}$ 種アデノウイルスで，この中には 40 型，41 型 がある。しかしこれ以外のアデノウイルスも下痢便検体 から検出される。 ヒトアストロウイルスはアストロウイ ルス科の Mamastrovirus 1 種に分類される古典的アスト ロウイルス（1 型〜 8 型）とその後に発見された MLB と VAがある。サポウイルスはノロウイルスと同じカリ シウイルス科に属し，頻度はノロウイルスに比べ少ない が，乳幼児の下痢症以外に時々集団食中毒の原因ウイル スとなる。ほかにピコルナウイルス科のウイルスがあり， エンテロウイルス, ヒトパレコウイルス, アイチウイル スが以前から知られていたが，近年コサウイルス，サ 
フォードウイルス，サリウイルスなど新たなウイルスが 複数検出されている.

\section{3. 臨 床症 状}

ウイルス性下痢症の症状として，下痢，嘔吐，発熱， 腹痛などがあるが, 症状からは病因ウイルスの特定はで きない. 最も重症となるウイルスはロタウイルスであり, 今でも開発途上国を中心として 215,000 人の死亡があ $\eta^{5)}$ ，日本でも年間数人が死亡する。発症後 1 から 2 週 間で自然に回復するが, 脱水がひどいと, 死亡する場合 もある。また，熱性けいれん，ロタウイルス脳炎・脳症 がある。ノロウイルスはロタウイルスに比べ，重症度， 下痢の期間ともに短いが，乳幼児の急性胃腸炎や成人の 散発性胃腸炎に加えて, 食中毒による集団感染や医療施 設，高齢者施設での施設内感染の原因となる。食中毒の 原因食材として以前はカキなどの海産物が知られていた が，現在は特定の食材というよりも感染経路不明の場合 が多い

\section{4. 下疡症ウイルスの疫学}

2009 年から 2013 年までの 4 年間に日本の札幌, 東京, 大阪, 静岡, 京都, 佐賀の 6 力所の小児科外来を訪れ, ウイルス性下痢症と考えられる乳幼児から得た便 2,381 検体からウイルスの検出を行った。 70.4\%からウイルス が検出され，ノロウイルスは $39.1 \%$ ，ロタウイルスは $20.1 \%$ で検出され，以下ヒトパレコウイルス（6.6\%), エンテロウイルス $(6.1 \%)$ ，アデノウイルス $(5.6 \%)$, サポウイルス $(4.8 \%)$ ，アストロウイルス $(2.3 \%)$ ，ア イチウイルス $(0.1 \%)$, ロタウイルス C $(0.1 \%)$ であっ だ）。この 4 年間の月別の分布を Fig. 1 に示す。この図 を見ると，ノロウイルスとロタウイルスの 2 つピーク が毎年あり，ノロウイルスのピークは 11 月ころから始 まり年末まで，ロタウイルスのピークは年明けの 3 月〜 4 月であることがわかる. かつてはロタウイルスの方が
多かったが，現在では前記のようにノロウイルスの検出 率の方が高い。さらにロタウイルスはかつて冬季乳幼児 嘔吐下痢症と呼ばれ，冬に多かったが現在ではピークが 晚冬から春季にと動いてきている.

ロタウイルスは前記のように $\mathrm{G}$ 遺伝子型として, G1，G2，G3，G4，G9の 5 つが日本でも主となる流行 型である。われわれの研究グループでは 1980 年代から 継続的に日本の小児科外来での患者検体からロタウイル スの検出を行っており，この結果を Fig. 2 に示す. 1980 年台から 2000 年初頭まで G1 が主流で，2003/04 年およ び 2010/11 年には G3 の割合が最頻出となった。この時 には G3 の遺伝子配列上での新しい変異株の出現が見ら れている。また，2013/14 年にはロタウイルスの検出率 そのものが大きく低下し，また検出された G1P[8] 株の VP7, VP4 以外の 9 本の遺伝子分節の配列を調べるとこ れまでの型とは大きく異なり，G2P[4]の遺伝子型の株 が持つ配列に近いということがわかった らは現在 DS-1 様 G1P[8] と呼ばれている。このウイル スの出現はロタウイルスが 11 本の遺伝子分節を持つウ イルスであることから生じている。すなわち二種類のウ イルスが一つの細胞に感染したことから起きる遺伝子分 節の交換（再集合体）によるもので，かつてからこの現 象はロタウイルスの多様性を生じさせる一因として知ら れていた。 日本では2011 年からロタウイルスワクチン の接種が始まったことがこの再集合株の出現に関わって いるのかもしれない。一方でこのような株は日本以外の アジアの国でも検出されている。2014/15 年にはロ夕ウ イルス検出率は $33 \%$ と再度上昇した。

ノロウイルスのうち，主となるノロウイルス GII には さらに多くの遺伝子型が存在する。乳幼児でのその分布 を Fig. 3 に示す。流行の主体は GII.4 遺伝子型の株であ る。さらに詳細な遺伝子の検索の結果, GII.4の中で変 異株が次々と生まれ，これが流行していることがわかっ た。2014/15 年にはこれまで検出が少なかった GII.17 株

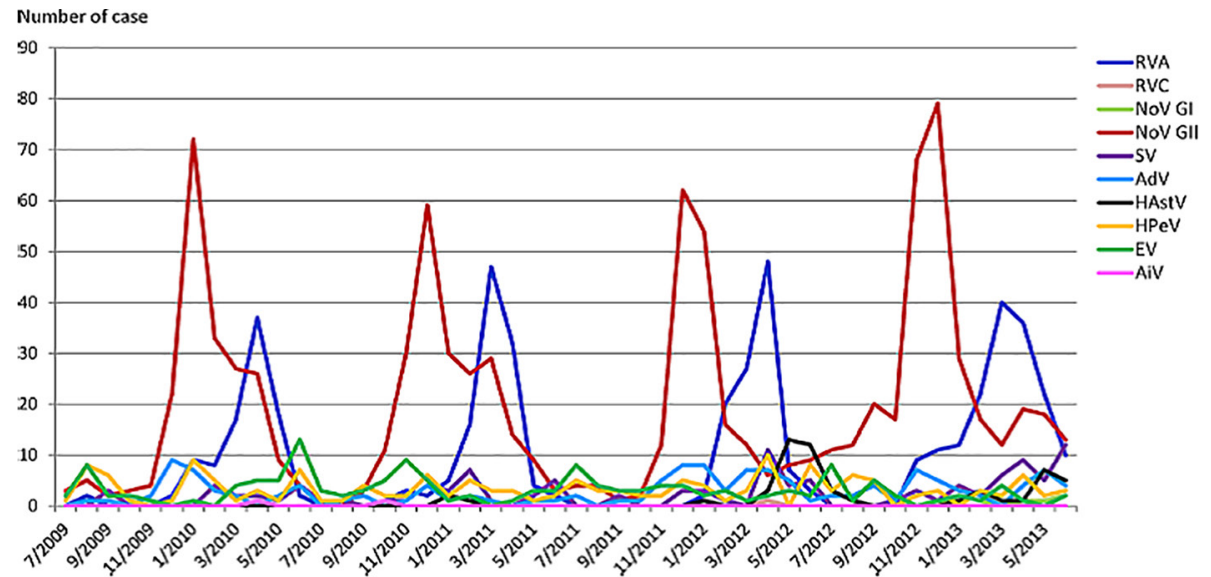

Fig. 1 Monthly distribution of viral infection among Japanese pediatric patients with acute gastroenteritis between 2009 and 2013. (Thongprachum A, et al., 2015) ${ }^{6}$ ) 
Percent (\%)

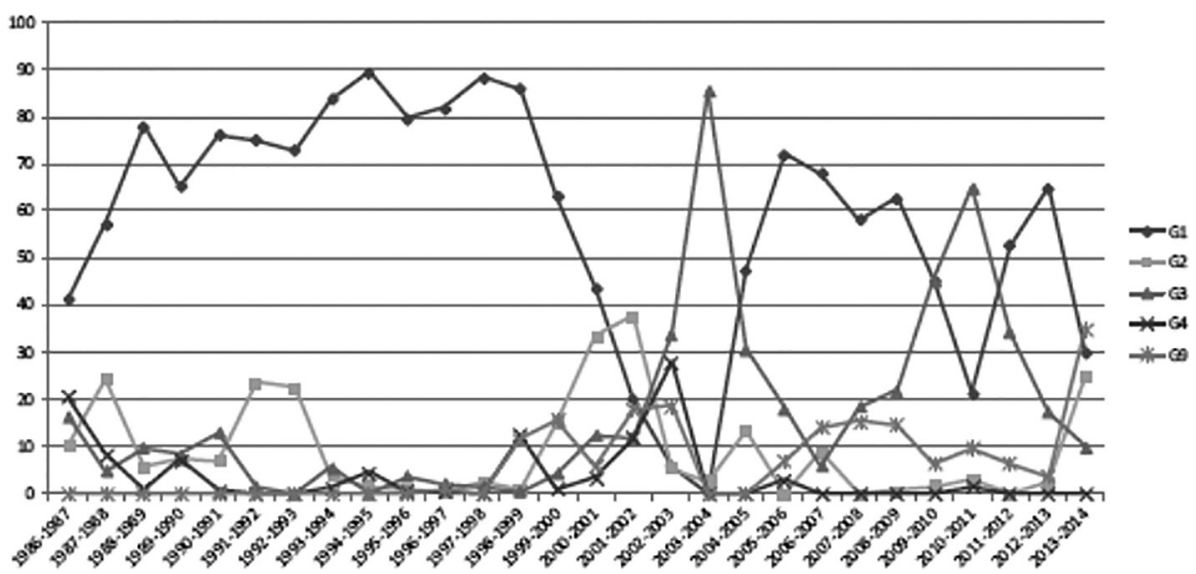

Fig. 2 Changing distribution of rotavirus $G$ genotype in Japanese pediatric out-patients with acute gastroenteritis. (Takanashi S, et al., 2017)

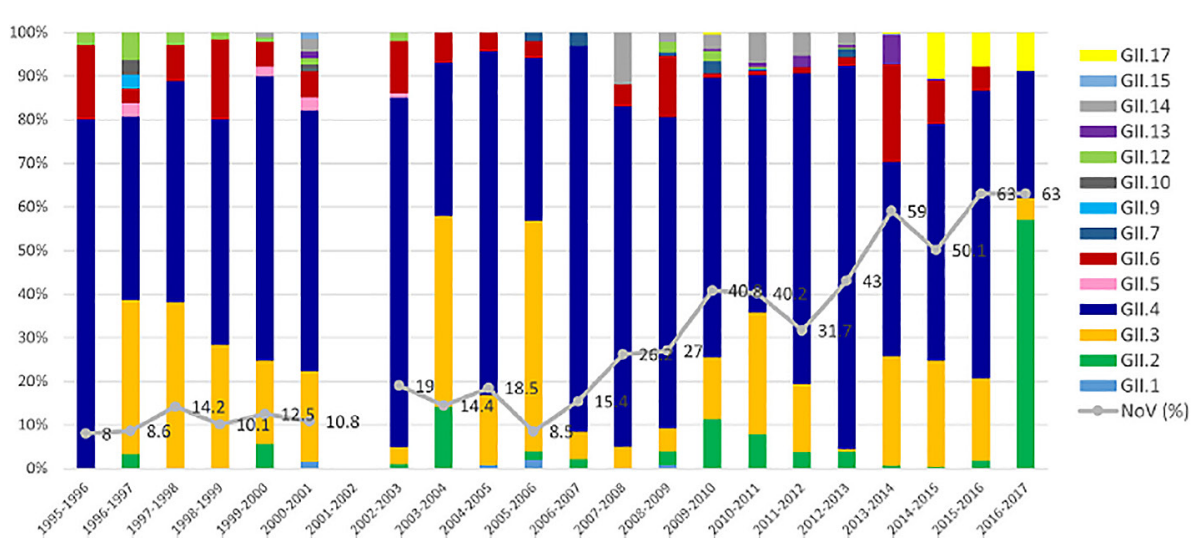

Fig. 3 Genotype distribution of norovirus detected in Japanese pediatric patients with acute gastroenteritis from 1995 to 2016. (Thongprachum A., 2017) ${ }^{8}$ )

が検出されている。 2016/17 年には主たる遺伝子型が GII. 2 へと変化した ${ }^{8)}$ 。この遺伝子型は ORF2 の遺伝子型 で表現されているが，実際には ORF1 領域と ORF2 領域 の異なる組換え型（キメラウイルス）が複数発見されて いる.すなわち 2016/17 年に流行した GII.2には GII.Pe/ GII.2, GII.P16/GII.2, GII.P17/GII.2 などの ORF1の異な る GII.2が検出されて扔り，その多様性を考えると，今 後，新しい流行型を予測するのは非常に難しい.

\section{5. 下痢症ウイルスの診断法}

臨床現場でのウイルスの診断にはイムノクロマトグラ フィーを利用した迅速診断キットが数社から市販されて 扔り，ロタウイルス，ノロウイルス，アデノウイルスで は保険も適用されている。ただし，ノロウイルスでは年 齢制限などの適用範囲がある。一方，ノロウイルスでは 数年㧍きに新しい変異株が出現するため, これまでのキッ トで新しい出現株の検出が可能か, 感度は十分かなど, 調べる必要がある。われわれの研究室では検体からウイ
ルス遺伝子を抽出し, RNA ウイルスでは逆転写反応を 行った後にPCR 法によってウイルスの検出をしている. 遺伝子型を調べるためには PCR 産物の配列解析を行い, 必要な場合はさらに広い領域の配列解析を行っている9

\section{6. 予 防 法}

ロタウイルスによる重症感染症を防ぐ目的で, ロタウ イルスワクチンが開発され, Rotarix と RotaTeq の二つ が世界的に使用されている。 日本でも2011 年と 2012 年 から市販されているが，現在のところ任意接種であるた め, 定期接種化が望まれている. 他の下痢症ウイルスに 対するワクチンは現在のところ市販されていない，下痢 症ウイルスの感染予防としてはノロウイルスを中心とし て，知られるようになってきた，手洗いなどの標準的な 予防策を行うとともに，便に排泄されたウイルスの二次 感染予防のためには排泄物の適切な処理が重要である. また，食品に混入したウイルスの不活化のためには加熱 処理が必要となる。 


\section{7.おわりに}

ノロウイルスは感染力が強いため, 乳幼児だけでなく 高齢者施設や病棟などでの施設内感染が毎年報告され， 2017 年 2 月には給食で使用したきざみノリの污染によ る小学校の集団食中毒が注目された。ささらに流行株が変 遷することから，ウイルスの進化が注目されている。 た, ようやくノロウイルスの試験管内培養法が確立さ $れ^{10)}$, 今後ノロウイルスの不活化, 治療薬の開発, 細胞 のウイルス感染機構の解明などウイルス学的研究が進む のではないかと期待されている。一方，ロタウイルスは ワクチン接種開始から 6 年が経過し，接種率が高まると ともにウイルスの流行株の変遷を今後も見守る必要があ る。今までは日本ではほとんど見られなかった G8 株が 2014 年にいくつかの地域で出現している ${ }^{11)}$. 世界では 第 6 の主要な型とされる G12 株が日本でも流行する可 能性や，他の哺乳類で見られる G5 や G6 などがヒトで も広がる可能性がある。ささらにサポウイルス，アストロ ウイルスや新しいピコルナウイルス科のウイルスが日本 でどのように分布しているかも注目されている。このよ うに今後も日本における下痢症ウイルスの疫学調査は継 続して行うことは必要である.

\section{文献}

1) Liu L, Oza S, Hoga D, et al. Global, regional, and national causes of child mortality in 2000-13, with projections, to inform post-2015 priorities: An updated systemic analysis. Lancet 2015; 385: 430-440.
2) Bányai K, Lászlóa B, Duqued J, et al. Systematic review of regional and temporal trends in global rotavirus strain diversity in the pre rotavirus vaccine era: Insights for understanding the impact of rotavirus vaccination programs. Vaccine, 2012; 305: A122-A130.

3) Matthijnssens J, Ciarlet M, Rahman M, et al. Recommendations for the classification of group A rotaviruses using all 11 genomic RNA segments. Arch Virol 2008; 153: 1621-1629.

4) Kroneman A, Vega E, Vennema H, et al. Proposal for a unified norovirus nomenclature and genotyping. Arch Virol 2013; 58: 2059-2068.

5) Tate JE, Burton AH, Boschi-Pinto C, et al. Global, Regional, and National Estimates of Rotavirus Mortality in Children $<5$ Years of Age, $2000 \pm 2013$. Clin Infect Dis 2016; 62 (Suppl 2): S96-105.

6) Thongprachum A, Takanashi S, Kalesaran AFC, et al. FourYear Study of Viruses That Cause Diarrhea in Japanese Pediatric Outpatients. J Med Virol 2015; 87:1141-1148.

7) Takanashi S, Thongprachum A, Okitsu S, et al. Molecular epidemiological traits of group A rotaviruses in Japanese children during transmission period of rotavirus vaccine implementation, 2011-2014. Clin Lab 2017; 63: 961-970.

8) Thongprachum A, Okitsu S, Khamrin P, et al. Emergence of norovirus GII.2 and its novel recombinant during the gastroenteritis outbreak in Japanese children in mid-2016. Infect Genet Evol 2017; 51: 86-88.

9) Thongprachum A, Khamrin P, Pham NTK, et al. Multiprec RT-PCR for rapid detection of viruses commonly causing diarrhea in pediatric patients. J Med Virol 2017; 89: 818-824.

10) Ettayebi K, Crawford SE, Murakami K, et al. Replication of human noroviruses in stem cell-derived human enteroids. Science 2016; 353:1387-1393.

11) Kondo K, Tsugawa $T$, Ono M, et al. Clinical and Molecular Characteristics of Human Rotavirus G8P[8] Outbreak Strain, Japan, 2014. Emerg Infect Dis 2017; 23: 968-972. 